\title{
The Right to Development in International Law: New Momentum Thirty Years Down the Line?
}

\author{
Karin Arts ${ }^{1}$ Atabongawung Tamo ${ }^{1}$
}

Published online: 24 October 2016

(C) The Author(s) 2016. This article is published with open access at Springerlink.com

\begin{abstract}
The right to development (RTD) is contested in international law, politics and practice. This remains the case, despite the 30-year existence of the United Nations Declaration on the Right to Development (UNDRTD), the many substantive leads that current international law provides, and the renewed inspiration that can be drawn from Agenda 2030 and its sustainable development goals. This article explores whether there is a possible new momentum for the RTD in international law. Deep substantive and political divisions about the exact content and implications of the RTD prevail between — and within — the North and the South. Up to now these divisions have stood in the way of achieving greater normative clarity, followup and implementation action. This state of affairs has directed us to adopt a pragmatic approach, by which we consider the scope for revitalizing the RTD through existing provisions of international law, rather than by creating additional normative frameworks. Thus, after a short sketch of the historical evolution of the RTD, we examine the nature, substance and implications of this right as conceived in the UNDRTD. Then, we pursue the question of how existing provisions of international law could be mobilized more explicitly for the sake of revitalizing the RTD and more in particular for its actual realization in the future. Three concrete means of implementation provide at least some prospect for positive change:
\end{abstract}

This article is an amended version of the 2016 'Preadvies' (Preliminary report) on 'Revitalizing the Right to Development in International Law' written by Arts and Tamo for the Royal Netherlands Society of International Law (KNVIR). Unless indicated otherwise, all internet material referred to in this article was last accessed in October 2016.

Karin Arts

arts@iss.nl

Atabongawung Tamo

atabongawung@iss.nl

1 International Institute of Social Studies (ISS), Erasmus University Rotterdam, Rotterdam, The Netherlands 
international cooperation for development, accountability and monitoring mechanisms, and regional and inter-regional instruments and procedures.

Keywords Right to development - Duty to cooperate - SDGs - UN treaty bodies · African Charter on Human and Peoples' Rights · Inclusive development . Accountability

\section{Introduction}

In December 2016, the United Nations Declaration on the Right to Development $\left(\right.$ UNDRTD ${ }^{1}$ will have been in existence for thirty years. This Declaration is revered as the first international instrument to express the individual as well as the collective right to development at a global level. The importance of the Declaration also (currently still) lies in the fact that it provides one of the few structured approaches to addressing development issues in a rights-based manner. Thus, while being a soft law instrument (as will be addressed below), the UNDRTD takes State contributions to development policies and development work at large out of the realm of voluntariness and charity and into the sphere of rights and required international cooperation, or the duty to cooperate. Furthermore, according to the Declaration, the Right to Development (RTD) focuses not only on equity and the indivisibility of human rights, but also on the importance of inclusive participation in development both as a means and as a goal. This is very much in line with what current conceptualizations of development, such as the 2015 sustainable development goals (SDGs), still emphasize today. ${ }^{2}$

Despite the significance of its content and approach, in practice the UNDRTD has not managed to inspire a great deal of concrete implementation efforts. In fact, due to the great substantive and political divisions prevailing between-and within - the North and the South about the exact substance and implications of the RTD, relatively little explicit follow-up has occurred. The 30th anniversary of the UNDRTD thus coincides with the continued acuteness of undertaking efforts to bring about, and further stimulate, development efforts, and with the substantive resonance between the UNDRTD and contemporary articulations of development concerns and agendas. This coincidence provides ample reasons for exploring

\footnotetext{
${ }^{1}$ UN Doc. A/RES/41/128, adopted on 4 December 1986, for its text see http://www.un.org/documents/ $\mathrm{ga} / \mathrm{res} / 41 / \mathrm{a} 41 \mathrm{r} 128 . \mathrm{htm}$.

2 Ibid., Art. 1(1) and Art. 2(1). The 17 SDGs are part of the United Nations' '2030 Agenda for Sustainable Development', or 'Agenda 2030'. They were adopted by the UN General Assembly on 25 September 2015. The document explicitly states that Agenda 2030 has been informed by 'other instruments such as the Declaration on the Right to Development' and recognizes the need to build societies 'that are based on respect for human rights (including the right to development)'. See UN Doc. A/RES/70/1, 21 October 2015, Declaration, respectively p. 4, para. 10 and p. 9 para. 35 . The SDGs took effect on 1 January 2016 (see SDG Declaration para. 21). The term 'participation' appears ten times in the 2030 Agenda for Sustainable Development: once in the Preamble, thrice in the Declaration (paras. 20, 27 and 44), thrice in the targets for the SDGs themselves (Goals 5.5, 6.b and 16.8) and thrice in the section on 'Means of Implementation' (paras. 70, 84 and 89). This does not at all imply, however, that the process of formulating Agenda 2030 has been sufficiently participatory. For critical accounts see e.g. Enns et al. (2014), pp. 358-375 and Gabizon (2016), pp. 99-110. The word 'inclusive' appears no less than 40 times in Agenda 2030.
} 
whether there is cause and space to revitalize the RTD in international law and, if so, how this could take shape.

Given the political controversies over the subject, in this article we consider the scope for revitalizing the RTD through existing international law instruments, rather than by creating additional normative frameworks. We examine the historical evolution, nature, substance and implications of the RTD as conceived in the UNDRTD. In addition, we pursue the question of how existing provisions of international law could be mobilized more explicitly for the sake of strengthening the position of the RTD in international law, and more in particular its implementation and actual realization in the future. This article adopts an analytical approach, and examines certain key concepts of international law. For example, we analyse how the RTD could be revitalized by focusing more on the concept of international cooperation in international law, and especially on the obligations related to this concept. We also explore how the United Nations 2030 Agenda for Sustainable Development, including the SDGs, could provide major momentum for stepping up activities that are essential for working towards realizing the RTD. We are of the opinion that, in order to help the process of paper commitments towards the RTD being turned into effective action on the ground, accountability and monitoring procedures are crucial. In that regard, we examine the potential of procedures in international human rights law, in addition to the scope for contributions from regional and inter-regional understandings of the RTD - especially in the African Union (AU) system and in the relations between the European Union (EU) and the African, Caribbean and Pacific Group of States (ACP). All of these explorations will reveal some new space for the RTD in international law and will raise some forward-looking thoughts for revitalizing this right.

\section{The Historical Evolution of the Right to Development}

Adopted by the UN General Assembly on 4 December $1986,{ }^{3}$ the UNDRTD proclaims that 'every human person and all peoples are entitled to participate in, contribute to, and enjoy economic, social, cultural and political development, in which all human rights and fundamental freedoms can be fully realized'. At the time, its adoption was a major formal breakthrough in North-South relations, especially for the "developing' ${ }^{5}$ country members of the UN. After all, the

\footnotetext{
3 UNDRTD, above n. 1.

4 Ibid., Art. 1(1).

5 For want of better terminology, this paper uses the broadly established terminology to refer to countries at opposite ends of the spectrum of levels of economic development. We note that the terms 'developing' and 'developed' might create false impressions, e.g. of human well-being and rights being looked after well in so-called developed countries and less well or hardly at all in so-called developing countries. In practice, there are also 'development' issues in the 'developed' world (also referred to as the North) and some 'developing' countries (also referred to as the South) manage relatively well within their circumstances. The KidsRights Index, a worldwide annual ranking on how States Parties to the UN Convention on the Rights of the Child are doing in terms of realizing children's rights, provides various examples of both categories. As we feel some level of uneasiness with the established terminology, in this paper we will use the terms in question in inverted commas. This matter is strongly acknowledged in the SDGs, above n. 2, which, contrary to the preceding Millennium Development Goals, apply universally
} 
convergence of human rights and development had only started to emerge following the political wind of decolonization. Especially newly independent African States articulated the RTD as a 'necessary companion of their newly acquired political emancipation'. ${ }^{6}$ In their original conceptualization, reportedly the RTD was perhaps meant to cover solely, or at least primarily, a collective peoples' right (of an erga omnes nature). ${ }^{7}$ Thus, the claim was unconventional concerning the classical individualistic paradigm of human rights. However, the RTD soon became acknowledged as an individual human right as well. Accordingly, by positioning both 'every human person' and 'all peoples' as holders of the RTD, the UNDRTD presents this right as both a collective and individual notion. ${ }^{8}$

As stated in the introduction, the UNDRTD is a soft law instrument. While the members of the UN have agreed to implement the Declaration, the exact nature of the obligations involved and of the modes of implementation have been the subject of intense debate for at least the last thirty years. The implementation and operationalization of the RTD have been hindered a great deal by political controversy and political considerations. 'Developed' countries have largely refused interpretations of the RTD that legally require them to give development assistance to particular 'developing' countries, while 'developing' countries continue to insist on the need for more international cooperation, including development assistance and concessions, a fairer international trade climate, access to technology and debt relief from 'developed' counties. Thus, the RTD has largely remained elusive. However, as will gradually be elaborated in this article, the UNDRTD is not the only legal instrument that is relevant for defining the substance and consequences of the RTD. Rather, despite the sketched controversies, various core elements of this right also appear in international legal instruments other than the UNDRTD and these could be drawn upon to a greater extent.

The post-1960s debate on the RTD revolved around what Balakrishnan Rajagopal has identified as:

[The] lack of democracy at the international level and the resulting concentration of economic and political power of the North; the rigged rules of the system which worked against developing countries; the precarious condition of self-determination in developing countries; the lack of effective sovereignty over natural resources due to the aggressive interventionist policies of powerful countries; and the prevalence of structural conditions that

\footnotetext{
Footnote 5 continued and 'involve the entire world, developed and developing countries alike' (ibid., p. 3, para. 5). This is indeed a major breakthrough.

6 Villaroman (2010), pp. 229-300. See also Cheru (2016), pp. 1268-1283.

7 Villaroman (2010), p. 300. The term erga omnes refers to international obligations (or, as in this context, a feature of a particular right) that are the concern of all States and that are held towards the international community at large. Accordingly, all States have a legitimate interest in upholding and enforcing such norms. See e.g. Frowein (2016).

8 Villaroman (2010), p. 300.
} 
prevented the state in the developing world from performing a more robust function in economic policy formulation, coordination, and implementation. ${ }^{9}$

Because of these concerns, some prominent scholars from 'developing' countries and elsewhere also began to champion the call for a change to these structural injustices. ${ }^{10}$ The RTD has since been 'about correcting what is wrong in the global economic order [especially as from] its inception, it was meant to address the effects of the asymmetrical relationship between the developed and developing countries'. 11

As Olav Stokke has noted, the situation in the late 1960s and 1970s was 'characterized by [yet] stronger, more determined, and more self-confident postures by Third World governments, manifest in their demand for [a New International Economic Order]'. ${ }^{12}$ According to Villaroman, although the post-World War II period saw the West:

trumpeting individual human rights guaranteed in the Universal Declaration of Human Rights and the two international human rights covenants, a significant number of developing countries were testing the waters [...] by crafting a collective right to development to bolster their demand for fundamental changes in their economic relationship with the developed world. ${ }^{13}$

This resulted in several relevant pronouncements in the late 1960s and 1970s. Prominent was the endorsement of core elements of a RTD in the Charter of Algiers, adopted by the first ministerial meeting ever of the Group of 77 'developing' countries, at their October 1967 meeting. ${ }^{14}$ The Charter stated among other things that:

The international community has an obligation to rectify these unfavourable trends and to create conditions under which all nations can enjoy economic and social well-being, and have the means to develop their respective resources to enable their peoples to lead a life free from want and fear. ${ }^{15}$

\footnotetext{
9 Rajagopal (2013), p. 899.

10 The first attempt to formulate a right to development is often attributed to the eminent Senegalese lawyer Kéba M'baye. See M'baye (1972), pp. 503-534. Selected other examples of relevant scholarship since then include: Bulajić (1986); Chowdhury et al. (1992); Karimova (2016) and work by Georges AbiSaab, Philip Alston, Mohamed Bedjaoui, Sakiko Fukuda-Parr, Stephen Marks, Nico Schrijver, Arjun Sengupta and many others.

11 Villaroman (2011), p. 14.

12 Stokke (2009), pp. 7-10.

13 Villaroman (2010), p. 300.

14 Meillan (2003), pp. 13-31. The G-77 was created in June 1964 by 77 'developing' country members of the UN. According to information available at http://www.g77.org/doc, the G-77 'provides the means for the countries of the South to articulate and promote their collective economic interests and enhance their joint negotiating capacity on all major international economic issues within the United Nations system, and promote South-South cooperation for development'. Since 1964 membership of the G-77 has grown to 134 'developing' countries. '[T] he original name was retained due to its historic significance.' Ibid.

15 Charter of Algiers, 10-25 October 1967, http://www.g77.org/doc/algier 1.htm, Part One, Section 3.
} 
In the same document, the G-77 at the time also expressed that 'the development of developing countries will benefit the developed countries as well', that the primary responsibility for their development rests on the developing countries and that developing countries were 'determined to contribute to one another's development'. In 1977 the next milestone occurred in the form of an explicit recognition of the RTD by the UN Commission on Human Rights in a Resolution that explicitly recognized 'the Right to Development as a human right' and commissioned a study on the subject. ${ }^{16}$ Two years later, the Commission on Human Rights repeated its recognition of the RTD and added 'that equality of opportunity for development is as much a prerogative of nations as of individuals within nations' ${ }^{17}$ Accordingly, after various studies and reports and much deliberation in the Commission on Human Rights and the UN General Assembly, the UNDRTD was formally adopted by the General Assembly in December 1986.

In the meantime, the RTD had also gained ground in some regional and interregional international legal instruments. As is discussed further in Sect. 4.3 below, the most prominent expression at a regional level is Article 22 of the 1981 African Charter on Human and Peoples' Rights. To date, that Charter remains the only hard law document bestowing an individual and collective RTD with binding and enforceable obligations imposed on States. ${ }^{18}$ In the Preamble to the African Charter, the African States involved stated their conviction that it is essential to pay a particular attention to the right to development'. ${ }^{19}$ According to Article 22, all peoples 'shall have the right to their economic, social and cultural development with due regard to their freedom and identity and in the equal enjoyment of the common heritage of mankind' and all States 'shall have the duty, individually or collectively, to ensure the exercise of the right to development'. The African Commission has dealt with at least seven complaint cases that are relevant to this provision. In response to a complaint that became known as the Endorois case, the African Commission found (in November 2009) that the government of Kenya had violated Article 22. This case will be further explained in Sect. 4.3 below.

\footnotetext{
${ }^{16}$ UN Commission on Human Rights, Res. 4 (XXXIII), 21 February 1977. For a more detailed overview of UN involvement in the recognition and definition of the RTD, see http://www.ohchr.org/EN/Issues/ Development/Pages/Backgroundrtd.aspx and http://legal.un.org/avl/pdf/ha/drd/drd_ph_e.pdf.

${ }^{17}$ UN Commission on Human Rights, Res. 5 (XXXV), 2 March 1979.

18 The African Charter on Human and Peoples' Rights, adopted in Nairobi on 27 June 1981, entered into force on 21 October 1986, http://www.achpr.org/instruments/achpr. All of Africa except South Sudan has ratified the Charter. For ratification details seehttp://www.achpr.org/instruments/achpr/ratification. The African Charter was drafted with the explicit intention of reflecting an African conceptualization of human rights. For in-depth analyses, see e.g. Ouguergouz (2003); Umozurike (1997); Murray (2005); or Viljoen (2012). The second version of the Arab Charter on Human Rights, adopted on 15 September 2004, entry into force on 15 March 2008, http://hrlibrary.umn.edu/instree/loas2005.html?msource= UNWDEC19001\&tr=y\&auid=3337655, in Art. 37 also recognizes the RTD as 'a fundamental human right' and requires all States 'to establish the development policies and to take the measures needed to guarantee this right. They have a duty to give effect to the values of solidarity and cooperation among them and at the international level with a view to eradicating poverty and achieving economic, social, cultural and political development. By virtue of this right, every citizen has the right to participate in the realization of development and to enjoy the benefits and fruits thereof.' No concrete follow-up seems to have been given to this provision so far.
}

${ }^{19}$ Ibid., Preamble para. 8. 
Another example, from the inter-regional level, is that of the treaties that through the years have formed the basis for development cooperation relations between the ACP Group (nowadays consisting of 79 States in Africa, the Caribbean and the Pacific), ${ }^{20}$ and the EU. While the respective Lomé Conventions and the Cotonou Partnership Agreement, that have been in place consecutively since 1975, did not directly refer to the RTD, their approach, contents and basic general principles certainly came a long way towards operationalizing the RTD in a comprehensive manner. An example is the integral understanding of 'development' as an objective and process to be pursued, with economic, social, cultural, political and possibly other relevant dimensions. Another illustration is the contractual approach, by which both the ACP and the EU States formally committed themselves, in binding legal instruments, to the principles, objectives, procedures and institutions for their development cooperation relations, and by which the EU bound itself to making available a specified set of resources in support of these relations. An additional main feature of the ACP-EU treaties that fits the outlook of the UNDRTD quite well is the central role they gradually assigned to human rights. ${ }^{21}$

At the global level, developments continued as well. The RTD was further reaffirmed in several international documents and fora, including at the World Conference on Human Rights held in Vienna in 1993. The Vienna Declaration and Programme of Action contained more than ten references to the RTD and/or the UNDRTD. $^{22}$ In a follow-up to the World Conference, in 1993 as well, the UN General Assembly established the post of High Commissioner for Human Rights. The Preamble to the Resolution involved reaffirmed 'that the right to development is a universal and inalienable right which is a fundamental part of the rights of the human person'. ${ }^{23}$ Among the responsibilities that the UN General Assembly assigned to the High Commissioner in the same Resolution was (and still is) the task to 'promote and protect the realization of the right to development and to enhance support from relevant bodies of the United Nations system for this purpose'. ${ }^{24}$ The Office of the High Commissioner for Human Rights (OHCHR) has since pursued this goal, among other things by initiating and supporting attempts to clarify and advocate the RTD. Several bodies were created in the process, and then serviced by the OHCHR. These included various Intergovernmental Working Groups on the Right to Development as of $1993,{ }^{25}$ a UN Independent Expert on the Right to Development (1999-2004), ${ }^{26}$ and a High-level Task Force on the Implementation of

\footnotetext{
${ }^{20}$ For more information on the history and composition of the ACP Group, see http://www.acp.int/ content/secretariat-acp.

${ }^{21}$ See e.g. Arts (1996), pp. 37-71; Holland (2002); Bartels (2005); or Arts (2008), pp. 217-250. For a relatively recent overview of the state of affairs in EU-ACP relations see Advisory Council of International Affairs (2015).

${ }^{22}$ Vienna Declaration and Programme of Action, adopted by the World Conference on Human Rights on 25 June 1993, UN Doc. A/CONF.157/23, 12 July 1993.

${ }^{23}$ UN Doc. A/RES/48/141, 20 December 1993, http://www.un.org/documents/ga/res/48/a48r141.htm.

${ }^{24}$ Ibid.

${ }^{25}$ http://www.ohchr.org/EN/Issues/Development/Pages/Documents.aspx.

${ }^{26}$ Appointed by the Commission on Human Rights, held by Arjun K. Sengupta from India between 1999 and 2004. See http://www.ohchr.org/EN/Issues/Poverty/Pages/ASengupta.aspx.
} 
the Right to Development (2004-2010). ${ }^{27}$ These bodies, among other things, have interpreted and analysed the scope and content of the RTD, the challenges of implementation, and recommended ways and means towards a global realization of the RTD. ${ }^{28}$

World leaders attending the September 2000 UN Millennium Summit-which adopted the Millennium Development Goals (MDGs) that would subsequently be in place until 2015 - also pledged the realization of the RTD. In particular, the Heads of State and Government expressed their commitment 'to making the right to development a reality for everyone and to freeing the entire human race from want'. ${ }^{29}$ Along the same lines, the Monterrey Consensus that emerged following the first International Conference on Finance for Development (2002) emphasized key elements of the UNDRTD by reinvigorating commitment on the part of the international community to support the development efforts of developing countries through international cooperation. ${ }^{30}$ Subsequent conferences have built upon the above agenda, including the 2015 Addis Ababa Third International Conference on Finance for Development where Heads of State and Government reaffirmed their 'strong political commitment to address the challenge of financing and creating an enabling environment at all levels for sustainable development in the spirit of global partnership and solidarity'. 31

As was already indicated at the start of this article, the recently endorsed UN SDGs also emphasize core elements of the RTD. While the SDGs are contained in a UN General Assembly Resolution, the experiences with their predecessors-the MDGs-have shown that, despite their soft law nature, such Goals can generate enormous momentum and can lead to unprecedented prioritization and intensification of implementation efforts. SDGs 16 and 17 are especially relevant for our purposes. SDG 16, among other things, focuses on promoting 'peaceful and inclusive societies for sustainable development', providing 'access to justice for all', and building 'effective, accountable and inclusive institutions at all levels'. SDG 17 highlights the need to strengthen the means of implementation (finance, technology, capacity building, trade, systemic issues) and to revitalize the Global Partnership for Sustainable Development. ${ }^{32}$ The interconnections between the SDGs and the RTD are evident. This was also reiterated recently by Martin Khor, Executive Director of the South Centre, at the Human Rights Council meeting held in commemoration of

\footnotetext{
27 http://www.ohchr.org/EN/Issues/Development/Pages/HighLevelTaskForce.aspx.

28 The background of the mandates of the different established UN bodies linked to the RTD is accessible via: http://www.ohchr.org/EN/Issues/Development/Pages/Documents.aspx.

29 UN General Assembly, 'United Nations Millennium Declaration', UN Doc. A/RES/55/2, 18 September 2000, para. 11. For general information on the Millennium Summit see e.g. http://www.un. org/en/events/pastevents/millennium_summit.shtml.

${ }^{30}$ Report of the Secretary-General, 'Outcome of the International Conference on Financing for Development', UN Doc. A/57/344, 23 August 2002.

31 See Addis Ababa Action Agenda of the Third International Conference on Financing for Development (Addis Ababa, Ethiopia, 13-16 July 2015), endorsed by the General Assembly in its Resolution 69/313, adopted on 27 July 2015 and published in UN Doc. A/RES/69/313, 17 August 2015, para. 1.

32 Above, n. 2.
} 
the 30th anniversary of the UNDRTD. ${ }^{33}$ According to Khor, " $t$ there is a close connection between the Right to Development and the SDGs. Fulfilling the SDGs would go a long way to realizing the right to development'. ${ }^{34}$ And,

[the] approach and instruments of the right to development would be useful to apply when implementing the SDGs. In turn the fulfilment of the SDGs would be helpful for the realization of the right to development. At the same time we should be mindful that there are limitations to the set of SDGs and to the SDG approach. This should be supplemented by other instruments and approaches that are needed for a comprehensive understanding of the dynamics of development and thus of the right to development. ${ }^{35}$

This outlook on the continued relevance of the RTD is shared by others. For instance, Martin Khor's reference to 'other instruments and approaches' could be interpreted as applying to human rights instruments and human rights-based approaches. While the SDGs show more reflections of these than the MDGs did, a call in support of human rights-based approaches to development is certainly still important as the impressive progressive evolution of international human rights law and the ratification records of international human rights law instruments that the world has witnessed have not yet generated sufficient progress on the ground. Concern for human rights drove Sakiko Fukuda-Parr to the statement that the RTD remains 'highly relevant to the real and concrete challenges to human rights in an increasingly integrated and unequal world of the twenty-first century'. According to Fukuda-Parr, its 'core claim to a socially just economic system, governed by rules and principles that protect human rights, is even more important in the twenty-first century as globalization proceeds at a rapid pace'. ${ }^{36}$ Fukuda-Parr also clarified that the UNDRTD is 'the only international human rights instrument that addresses the need for joint international action to address the human rights consequences of global economic arrangements'. 37

The very latest development in the UN history of the RTD is the controversial Human Rights Council decision to appoint a Special Rapporteur on the RTD (for a period of three years as of September 2016), ${ }^{38}$ mandated to contribute to the UN Working Group on the Right to Development and to 'the promotion, protection and

\footnotetext{
33 This meeting was held in Geneva on 15 June 2016. For a report on this meeting, see http://www.ohchr. org/en/NewsEvents/Pages/DisplayNews.aspx?NewsID=20108\&LangID=E.

34 South Centre, 'The Right to Development at 30: Looking Back and Forward', South News, no. 107, 17 June 2016, http://us5.campaign-archive2.com/?u=fa9cf38799136b5660f367ba6\&id=3a9a00a980, p. 6.

35 Ibid., at pp. 7-8.

36 Fukuda-Parr (2012), pp. 839-864, at p. 840.

37 Ibid.

38 Human Rights Council, 'Resolution on the Right to Development', UN Doc. A/HRC/33/L.29, 27 September 2016, para. 14. This resolution was adopted by 34 votes in favour (including China, Russia, Saudi Arabia and South Africa), 2 votes against (France and the United Kingdom (UK)) and 11 abstentions (including Germany, the Netherlands, Slovenia and Switzerland). While at the time of writing the final official voting records were not yet available, various sources, including http://www.unwatch. org/resolutions-voting-results-33rd-hrc-session/ and http://webtv.un.org/watch/ahrc331.29-vote-item339th-meeting-33rd-regular-session-of-human-rights-council/5145201561001, revealed that the EU, UK and Switzerland found the appointment of a Special Rapporteur on the RTD undesirable.
} 
fulfilment of the rights to development in the context of the coherent and integrated implementation of the 2030 Agenda for Sustainable Development and other internationally agreed outcomes of $2015,{ }^{39}$ In addition, the new Special Rapporteur is supposed:

to engage and support efforts to mainstream the right to development among various United Nations bodies, development agencies, international development, financial and trade institutions, and to submit proposals aimed at strengthening the revitalized partnership for sustainable development from the perspective of the right to development. ${ }^{40}$

Finally, the new Special Rapporteur can submit studies (on request by the Working Group on the Right to Development or the Human Rights Council) and is required to submit an annual report on her/his activities to the Human Rights Council and the UN General Assembly.

The above has traced the evolution and the continued relevance of the concept of the RTD and has pointed at the usefulness of involving the various hard and soft law international instruments that are currently available in addition to the UNDRTD. Especially selected global international human rights instruments, regional and inter-regional instruments, and the SDGs have potentially strong contributions to make, as will be further explored in Sect. 4. Proceeding from this background, we now first move to the substance and implications of the RTD as conceived in the UNDRTD.

\section{The Right to Development: Substance and Implications as Conceived in the UN Declaration}

In 1986 the UNDRTD was adopted with 146 votes in favour, only one opposing vote and eight abstentions. ${ }^{41}$ As we have noted earlier in this article, despite this relatively favourable voting record on the Declaration, the RTD always has been, and remains, controversial. In the words of Sakiko Fukuda-Parr, the UNDRTD:

has been widely criticized as too poorly written, containing too much ambiguity over basic issues, such as whether this is a collective or an individual right, to provide a basis for defining a conceptually robust human right that would have significant meaning for improving human welfare. ${ }^{42}$

In this light, it is now important to review the content of the UNDRTD, in particular as regards the nature and substance of the RTD and in terms of the implementation

\footnotetext{
39 According to the resolution (ibid., para. 14b), these agreements include the Sendai Framework for Disaster Risk Reduction, the earlier mentioned Addis Ababa Action Agenda of the Third International Conference on Financing for Development and the Paris Agreement on Climate Change.

40 Ibid., para. 14(c).

41 The opposing vote came from the United States of America, while Denmark, the Federal Republic of Germany, Finland, Iceland, Israel, Japan, Sweden and the UK abstained.

42 Fukuda-Parr (2012), p. 845. See also e.g. Ibhawoh (2011), pp. 76-104.
} 
obligations specified. The next two sub-sections of this article present the findings of a close analysis of the full text of the UN Declaration. They broadly portray all the UNDRTD provisions that are relevant for understanding the nature, content and the implementation framework of the RTD, as originally envisaged. This amounts to an analysis of nearly all of the text of the Declaration.

\subsection{The Nature and Content of the RTD according to the UN Declaration}

The Preamble to the UNDRTD clarifies right at the start that the document did not emerge out of the blue but that it already had a clear basis in existing provisions of international law at the time of its adoption. This was done through the inclusion of formal cross-references to the Charter of the United Nations, the Universal Declaration of Human Rights, the International Covenants on Economic, Social and Cultural Rights and on Civil and Political Rights, and to:

the relevant agreements, conventions, resolutions, recommendations and other instruments of the United Nations and its specialized agencies concerning the integral development of the human being, economic and social progress and development of all peoples, including those instruments concerning decolonization, the prevention of discrimination, respect for and observance of, human rights and fundamental freedoms, the maintenance of international peace and security and the further promotion of friendly relations and cooperation among States in accordance with the Charter. ${ }^{43}$

The Preamble to the UNDRTD defines the term 'development' fairly comprehensively, as follows:

a comprehensive economic, social, cultural and political process, which aims at the constant improvement of the well-being of the entire population and of all individuals on the basis of their active, free and meaningful participation in development and in the fair distribution of benefits resulting therefrom. ${ }^{44}$

Article 1 of the Declaration squarely qualifies the RTD as 'an inalienable human right' and formulates an entitlement for humans 'to participate in, contribute to, and enjoy economic, social, cultural and political development, in which all human rights [...] can be fully realized'. Overall, the Declaration clearly has an anthropocentric outlook. This is expressed, inter alia, in that the Declaration recognizes respectively 'the human person as the central subject of development', the human being as 'the main participant and beneficiary of development' and 'the active participant and beneficiary of the right to development'. ${ }^{45}$ This might explain why, despite the fact that the development of international environmental law was well on its way by 1986, the UNDRTD pays no attention to ecological or sustainability concerns at all. However, entirely in line with current international

\footnotetext{
${ }^{43}$ UNDRTD, above n. 1, Preamble para. 5, for the other cross-references see paras. 1, 3, 4 and 8 , and Arts. 3(2) and 9(2).

44 Ibid.

45 Ibid., Preamble para. 2.
} 
development priorities, the Declaration does explicitly pursue development as an inclusive notion, by emphasizing non-discrimination and equality of opportunity for all, which are to be enjoyed by 'every human person and all peoples' ${ }^{46}$

According to the latter, both every human person and all peoples are the holders of the RTD. The duty bearers are a diffuse set of actors. All human beings 'have a responsibility for development'. ${ }^{47}$ States, however, clearly have 'the primary responsibility for the creation of national and international conditions favourable' to the $\mathrm{RTD}^{48}$ and are required 'to take steps, individually and collectively'. ${ }^{49}$

All in all, the substantive picture of the nature and content of the RTD that emerges from the UN Declaration is still rather abstract and does not necessarily translate easily into concrete implementation obligations. This is perhaps exacerbated by the penultimate provision of the Declaration which stipulates that "[a]ll the aspects of the right to development set forth in the present Declaration are indivisible and interdependent and each of them should be considered in the context of the whole'. While not all details concerning the individual and collective dimensions of the RTD may be entirely clear, it is nevertheless a fact that the UNDRTD posits development unequivocally as a human right. This makes it pertinent to now explore the vision of the UNDRTD on the possible implications of this right in terms of concrete implementation obligations. According to the former Independent Expert on the Right to Development, Arjun Sengupta, this requires a '[yet] more nuanced explanation'.50

\subsection{The Obligations to Implement Formulated in the UN Declaration}

The most general vision on the action perspective that emerges from the existence of the RTD is provided in the closing provision of the UNDRTD: 'Steps should be taken to ensure the full exercise and progressive enhancement of the right to development, including the formulation, adoption and implementation of policy, legislative and other measures at the national and international levels' ${ }^{51}$ This formulation reinforces the idea that States are the primary duty bearers in relation to the RTD as policy-making, law-making and the adoption of other measures are largely, if not exclusively, within the domain of the State. The only implementation obligation specified for individuals is that all human beings should "promote and

\footnotetext{
46 Ibid., Art. 1(1). The UNDRTD Preamble para. 8, refers to respect for human rights 'without distinction of any kind such as race, colour, sex, language, religion, political or other opinion, national or social origin, property, birth or other status'. According to para. 16: 'equality of opportunity for development is a prerogative both of nations and of individuals who make up nations'. Art. 8(1) provides that in their national implementation measures, States 'shall ensure, inter alia, equality of opportunity for all in their access to basic resources, education, health services, food, housing, employment and the fair distribution of income. Effective measures should be taken to ensure that women have an active role in the development process'.

47 Ibid., Art. 2(2).

48 Ibid., Art. 3(1).

49 Ibid., Art. 4(1).

50 Sengupta (2013), pp. 67-87, at p. 67.

51 UNDRTD, above n. 1, Art. 10.
} 
protect an appropriate political, social and economic order for development' ${ }^{52}$ This is indeed no small task and it is even questionable whether this is doable at all. While the role of individual human beings as duty bearers is not developed further, the UN Declaration provides some more concrete leads as to the implementation obligations of States. Accordingly, States have the duty to:

- 'formulate appropriate national development policies' ${ }^{53}$

- 'undertake, at the national level, all necessary measures for the realization of the right to development'; ${ }^{54}$

- 'take steps, individually and collectively, to formulate international development policies ${ }^{55}$ that pursue the full realization of the RTD;

- encourage 'the observance and realization of human rights' and to cooperate for this purpose ${ }^{56}$

- 'take steps to eliminate obstacles to development resulting from failure to observe civil and political rights, as well as economic, social and cultural rights'; ${ }^{57}$ and

- 'encourage popular participation in all spheres as an important factor in development and in the full realization of all human rights' ${ }^{58}$

This list embodies a combination of national and international implementation obligations. These were not made strongly dependent on one another, although Article 4(2) of the UNDRTD refers to effective international cooperation as a 'complement to the efforts of developing countries'. In addition-according to Article 9(1) of the UNDRTD mentioned earlier-national and international implementation obligations are to be seen as 'indivisible and interdependent' and to be considered 'in the context of the whole' Declaration. Obviously, the notion of solidarity, translating into a duty to cooperate and to actively engage in international cooperation and assistance for development, forms another core implementation obligation concerning the RTD. Article 3(1) of the UN Declaration proclaims that: 'States have the responsibility for the creation of national and international conditions favourable to the realization of the right to development'. This entails that they 'have the duty to cooperate with each other in ensuring development and eliminating obstacles to development'. 59

\footnotetext{
52 Ibid., Art. 2(2). The same provision also refers to the 'human rights and fundamental freedoms' of individuals, and 'their duties to the community'. The latter is another illustration of the fact that the intellectual minds behind the UN Declaration were interested in balancing individual and collective notions of human rights, and of development, more than had been (and still is) done in traditional international human rights law with its predominantly individualistic focus.

53 Ibid., Art. 2(3).

54 Ibid., Art. 8(1).

55 Ibid., Art. 4(1).

56 Ibid., Arts. 3(3) and 6(1).

57 Ibid., Art. 6(3).

58 Ibid., Art. 8(1).

59 Ibid., Art. 3(3).
} 
As briefly stated already in the introduction to this article, the duty to formulate appropriate international development policies and to provide effective international cooperation are among the most controversial elements of the UNDRTD. ${ }^{60}$ From one perspective the level of controversy is perhaps understandable, given the fact that 'developed' countries would need to invest significantly in order to reach the required level of effort. From other perspectives this is less the case. For example, for a long time the same 'developed' countries have controlled the terms of international trade resulting among other things in a World Trade Organization regime that does not fully look after the trade interests of developing States, to put it mildly. The Doha Round, a negotiation process that was launched in November 2001 and that is also referred to as the Doha Development Agenda, could possibly remedy this (if only to some extent) as its 'fundamental objective is to improve the trading prospects of developing countries' ${ }^{61}$ The Round is still ongoing, however, if not in a deadlock.

In addition, the duty to cooperate in pursuit of the objectives of the RTD is nothing new at all. At the time of the adoption of the UNDRTD, the concept had already been expressed in several international instruments, most notably in the UN Charter. The latter lists achieving 'international cooperation in solving international problems of an economic, social, cultural or humanitarian character, and in promoting and encouraging respect for human rights' among the purposes of the UN. ${ }^{62}$ By UN Charter Articles 55 and 56 all UN Member States pledged 'to take joint and separate action' to achieve:

(a) higher standards of living, full employment, and conditions of economic and social progress and development;

(b) solutions of international economic, social, health and related problems: [...]

(c) universal respect for, and observance of, human rights [...]

In a nutshell, this amounts to the core of the RTD as conceived in the UNDRTD as well. ${ }^{63}$ Nevertheless, among 'developed' States there has hardly been any formally acknowledged progress in the recognition and application of these aspects of the RTD. Instead, the ideological divide over the matter continues to cause tension between 'developing' and 'developed' countries. ${ }^{64}$ As a result of their belief

\footnotetext{
${ }^{60}$ See e.g. Piron (2002), p. 11.

${ }^{61}$ World Trade Organization, 'The Doha Round', https://www.wto.org/english/tratop_e/dda_e/dda_e. htm. See also Scott and Harnam (2013), pp. 1361-1376; Cheru (2016), pp. 1278-1279.

${ }^{62}$ Charter of the United Nations, adopted in San Francisco, 26 June 1945, Art. 1(3).

${ }^{63}$ Subsequently, a host of UN resolutions built on this UN Charter mandate. Examples include the following UN General Assembly resolutions: (1) 'Declaration on Principles of International Law Concerning Friendly Relations and Cooperation Among States in accordance with the Charter of the United Nations', UN Doc. A/RES/25/2625, 24 October 1970; (2) 'Declaration on the Establishment of a New International Economic Order', UN Doc. A/RES/S-6/3201, 1 May 1974; (3) 'Programme of Action on the Establishment of a New International Economic Order', UN Doc. A/RES/S-6/3202, 1 May 1974; and (4) 'Charter of Economic Rights and Duties of States', UN Doc. A/RES/29/3281, 12 December 1974. ${ }^{64}$ See e.g. the position forwarded in the submission of Egypt on behalf of the Non-Aligned Movement (NAM) in the follow-up to Human Rights Council resolution 25/15, UN Doc. A/HRC/RES/15/25, 7 October 2010, available at http://www.ohchr.org/Documents/Issues/Development/Session12/NAM.pdf. For some background information on the NAM, see e.g. http://www.nti.org/learn/treaties-and-regimes/ non-aligned-movement-nam/.
} 
in the core content of the RTD and/or frustration about the lack of progress in practice, many 'developing' countries advocate the adoption of a treaty that would codify the RTD in a global hard law instrument setting out both the substance and implementation requirements of this right. Many 'developed' countries maintain the position, however, that the RTD is 'just' a combination of other existing rights and does not incur new legally binding obligations, or that the RTD represents merely an aspiration and not a right at all. A significant number of scholars have attempted to either justify or discount the legal basis for enforceable external obligations on the part of rich countries regarding international cooperation between such rich countries and poorer countries in the pursuit of the realization of the RTD. ${ }^{65}$ In Sect. 4.1 below we will present more details of the substance of the duty to cooperate in the context of the RTD.

A last set of implementation obligations that emerges from the UNDRTD relates to the structural nature of the development agenda. It relates to the obstacles encountered in realizing this agenda and is expressed in various references to the need to establish 'a new international economic order based on sovereign equality, interdependence, mutual interest and co-operation among all States' ${ }^{66}$ According to the UNDRTD's Article 4(2):

Sustained action is required to promote more rapid development of developing countries. As a complement to the efforts of developing countries, effective international co-operation is essential in providing these countries with appropriate means and facilities to foster their comprehensive development.

Article 5 refers to the need to eliminate human rights violations:

resulting from apartheid, all forms of racism and racial discrimination, colonialism, foreign domination and occupation, aggression, foreign interference and threats against national sovereignty, national unity and territorial integrity, threats of war and refusal to recognize the fundamental right of peoples to self-determination.

Article 7 of the UN Declaration adds another realm by raising the importance of action for international peace and security and for achieving disarmament. In the context of the national implementation measures to be taken, Article 8(1) of the UNDRTD prescribes that '[a]ppropriate economic and social reforms should be carried out with a view to eradicating all social injustices'. It is no surprise that on these structural elements of the UNDRTD, which so directly raise current economic structures and interests, progress is most difficult to find of all.

So what then, overall, is the significance of the UNDRTD? Elements of an answer to this question can be derived from the following statement by the former UN High Commissioner for Human Rights Navi Pillay-who has been a great advocate of the RTD—in her foreword to a book published on the occasion of the

\footnotetext{
65 For a cluster of arguments see e.g. Salomon (2007); Alston (1988) pp. 3-40; Vandenbogaerde (2013), pp. 187-209.

66 UNDRTD, above n. 1, Art. 3(3). See also Preamble para. 15.
} 
25th anniversary of the UNDRTD, addressing the course of affairs since the adoption of the Declaration:

We live in challenging times. Across the globe, millions are suffering the merciless, often devastating, effects of the many global crises of our age. The global financial and economic crisis, the food crisis, the energy crisis and the climate crisis have converged in a multi-front assault on human dignity. And our institutions of governance, at both the global and national levels, have been at best negligent, and at times complicit, in this onslaught. [...] This was not the vision of [...] the Declaration on the Right to Development [...]. A debate has been raging in the halls of the United Nations and beyond. On one side, proponents of the right to development assert its relevance (or even primacy) and, on the other, sceptics (and rejectionists) relegate this right to secondary importance, or even deny its very existence. Unfortunately, while generating plenty of academic interest and stimulating political theatre, that debate has done little to free the right to development from the conceptual mud and political quicksand in which it has been mired all these years. ${ }^{67}$

In other words, an important substantive vision has been developed in the form of the RTD, but concrete follow-up action is still wanting. In this context, we also agree with a slightly adjusted version of Fukuda-Parr's follow-up remark to her above assessment of the UN Declaration: '[i]ts instrumental value lies in introducing human rights norms and standards into global governance, and [in calling for] effecting reforms in national and international policies' ${ }^{68}$

In light of the fierce political controversy over certain key aspects of the RTD, as outlined above, and the urgent need to make headway, we advocate a pragmatic approach for revitalizing its implementation. Rather than seeking recourse to the creation of new legal instruments, such as a treaty or framework convention on the RTD, in our view the most promising — though difficult-way forward is through mobilizing existing provisions of international law. This entails drawing firmer attention to relevant provisions in already existing instruments, (re)interpreting such instruments where appropriate and feasible, finding new momentum for example in the SDGs, and creating at least rudimentary accountability through conducting international monitoring processes or using regional and inter-regional mechanisms where available. Some aspects of these suggestions will be examined below.

\section{Revitalizing the Implementation of the Right to Development by Mobilizing Existing Provisions of International Law and Building on the Momentum of the SDGs}

This article has so far indicated that there is quite a bit of ground to build on in international law relevant to the RTD, contested as it is. Nevertheless, 70 years after the adoption of the UN Charter and 30 years after the adoption of the UNDRTD,

\footnotetext{
67 Pillay (2013), pp. iii-v, at p. iii.

${ }^{68}$ Fukuda-Parr (2012), p. 857.
} 
still very little real RTD implementation practice has been achieved. This does not mean, however, that no progress at all has been made on tackling development issues. On the contrary, in relation to certain persistent problems such as for example under-five child mortality - which has halved in the last decades-and child poverty, tremendous achievements can be noted. According to UNICEF's report The State of the World's Children 2016: A Fair Chance for Every Child, children born today 'are over 40 per cent more likely to survive to their fifth birthday and more likely to be in school ${ }^{\prime 69}$ than was the case in the year 2000. Even on child poverty and child mortality, however, according to UNICEF much more action is still badly needed, if only because:

[...] in the midst of progress, millions of children continue to live-and diein unconscionable conditions. In 2015, an estimated 5.9 million children died before reaching age 5, mostly as a result of diseases that can be readily and affordably prevented and treated. Millions more children are still denied access to education simply because their parents are poor or from a stigmatized group, because they were born female, or because they are growing up in countries affected by conflict or chronic crises. And even though poverty is falling globally, nearly half of the world's extreme poor are children, and many more experience multiple dimensions of poverty in their lives. $^{70}$

Clearly, the MDGs have played a positive role in the realization of the abovementioned successes in combating poverty and under-five child mortality. They certainly have managed to bring about renewed momentum for development goals and targets, even though they grossly restricted the agenda to eight crucial, but not all-encompassing Goals. In addition to the existing hard law provisions in the UN Convention on the Rights of the Child, no less than four out of the eight soft law MDGs specifically addressed issues concerning poverty or child mortality. This may be a basis for explaining the relatively positive changes for children since the year $2000 .^{71}$ In other words, the MDG example suggests that old/existing law can obtain impetus from new political mobilization and momentum. This sparks hope in terms of the to be expected impact of the-more comprehensive, and more rightsoriented-SDGs. ${ }^{72}$

\footnotetext{
${ }^{69}$ UNICEF (2016), p. 3.

70 Ibid.

71 These were, respectively, MDG 1 on eradicating extreme poverty and hunger, MGD 4 on reducing child mortality, MDG 5 on improving maternal health and MDG 6 on combating HIV/AIDS, malaria and other diseases. Another explicitly child-related MDG was MDG2, focusing on achieving universal primary education. See e.g. http://www.un.org/millenniumgoals/.

72 As our introduction already revealed, above n. 2, paras. 10 and 35, Agenda 2030 was 'informed by [...] the Declaration on the Right to Development' and sees societies that 'are based on respect for human rights (including the right to development)' as a necessity for realizing sustainable development. Although Agenda 2030 overall contains a good number of references to human rights, the Goals and Targets themselves hardly contain any rights language. This is an opportunity lost to truly reconcile the three dimensions of sustainable development (economic, social and environmental) that Agenda 2030 seeks to integrate and balance. Ibid., Preamble para. 4; Declaration paras. 2 and 5; Follow-up and Review section para. 74(c). See also Razavi (2016), pp. 24-41.
} 
If one analyses the existing legal provisions which are relevant to the RTD, including the hard and soft law that were already reviewed in this article, then three common substantive orientations emerge that are crucial for improving the implementation record. Firstly, across older and newer instruments, including the SDGs, ${ }^{73}$ a strong call for inclusive development appears. This element has evolved most strongly out of the three orientations presented here. It entails, inter alia, that development objectives, targets and interventions should be non-discriminatory. The non-discrimination principle has a strong status both in international and national law. It has found its place in international human rights law but also in international trade law. ${ }^{74}$ Pursuing inclusive, non-discriminatory development and/ or equal development opportunities implies special attention for the position, needs and rights of vulnerable, marginalized and/or discriminated people. These will often include women, children, persons with disabilities, indigenous people(s) and rural populations. The non-discrimination principle is a core element of human rightsbased approaches to development and, as such, has gained more prominence in development practice than in the past. It is a crucial key to bringing home development for all.

Secondly, there is a strong need for comprehensive and coherent approaches that seek to integrate, and possibly balance, the various interests, needs and rights that come together in the concept of sustainable development and the associated implementation agenda. This entails adequately looking after economic, social, cultural, political and other relevant dimensions and manifestations of development. This also involves considering both human and ecological needs, and looking for normative and policy coherence. As observed before, the UNDRTD does not contain any environmental provisions. Consequently, in that respect it is incomplete and/or out of date. The SDGs are more progressive as far as this is concerned and explicitly seek to integrate and balance the economic, social and environmental dimensions of sustainable development. ${ }^{75}$ This SDG consensus should be built upon in the future.

Thirdly, to advance the RTD structurally, a new international order has to be pursued which would redress the current injustices in international economic and trade law, and allow for more forceful action on global challenges such as climate change and concerning financing development. This has been the elephant in too

\footnotetext{
73 See e.g. Razavi (2016), p. 27.

${ }^{74}$ Most of the global UN human rights treaties contain non-discrimination clauses. One of the more recent ones is Art. 5 of the Convention on the Rights of People with Disabilities. This provision synthesizes the current consensus on the meaning and implications of the non-discrimination principle in international human rights law as follows. According to para. 1 'all persons are equal before and under the law and are entitled without any discrimination to the equal protection and equal benefit of the law'. According to para. 2 'States Parties shall prohibit all discrimination on the basis of disability and guarantee to persons with disabilities equal and effective legal protection against discrimination on all grounds'. According to para. 4: 'Specific measures which are necessary to accelerate or achieve de facto equality of persons with disabilities shall not be considered discrimination'. An example from international trade law is the most favoured nations clause by which, according to the World Trade Organization, ' $[\mathrm{u}]$ nder the WTO agreements, countries cannot normally discriminate between their trading partners', see https://www.wto.org/english/thewto_e/whatis_e/tif_e/fact2_e.htm.

75 See Razavi (2016), p. 29.
} 
many relevant rooms for too long, though, both at international and national levels. As described in Sect. 3.2, this element of the RTD has received little follow-up. Hence is it no surprise that MDG 8, on the Global Partnership for Development, ${ }^{76}$ also has been labelled 'the most neglected of all MDGs' ${ }^{77}$ Progress in this area has been very difficult and slow and there is not much reason to believe that this picture will change drastically in the near future.

In the next section we will nevertheless review the scope for revitalizing the implementation of the RTD. In doing so we will focus on three concrete means of implementation for which we believe there to be sufficient leads for seeing at least some prospect for positive change. These means are: international cooperation, accountability mechanisms and regional and inter-regional instruments and procedures.

\subsection{Advancing International Cooperation}

As explained in Sect. 3.2, the duty to cooperate for international development is a long-standing element of international law. More in particular, it is a standing feature of various global and widely ratified UN human rights treaties. For example, the general implementation article of the 1966 International Covenant on Economic, Social and Cultural Rights already specified that States Parties to that Covenant shall 'take steps, individually and through international assistance and cooperation, especially economic and technical' to realize the Covenant. ${ }^{78}$ While the International Covenant on Civil and Political Rights, the International Convention on the Elimination of All Forms of Racial Discrimination, the Convention on the Elimination of all Forms of Discrimination Against Women, the Convention Against Torture and the Migrant Workers Convention all lack such an international cooperation provision, some other global UN human rights treaties have ever more elaborate stipulations on this aspect.

Accordingly, the general implementation article of the 1989 UN Convention on the Rights of the Child (Article 4) provides that '[w]ith regard to economic, social and cultural rights, States Parties shall undertake such [implementation] measures [...] where needed, within the framework of international co-operation'. More specific aspects are highlighted in references to undertakings to cooperate internationally on: the production, exchange and dissemination of information

\footnotetext{
76 This Global Partnership entailed: (1) developing 'an open, rule-based, predictable, non-discriminatory trading and financial system' (Target 8.A); (2) addressing 'the special needs of least developed countries' (Target 8.B); (3) dealing 'comprehensively with the debt problems of developing countries' (Target 8.D.); (4) providing '[i]n cooperation with pharmaceutical companies, [...] access to affordable essential drugs in developing countries' (Target 8.E); and (5) making available, '[i]n cooperation with the private sector, [...] benefits of new technologies, especially information and communications' (Target 8.F). See http:// www.un.org/millenniumgoals/global.shtml.

77 Razavi (2016), p. 27. See also Turshen (2014), pp. 345-357.

78 International Covenant on Economic, Social and Cultural Rights, Art. 2(1), adopted 16 December 1966, entry into force 3 January 1976, 164 States Parties on 1 July 2016 according to https://treaties.un. org. Art. 11 introduced international cooperation obligations in relation to realizing the right to food and Art. 15 recognized 'the benefits to be derived from the encouragement and development of international contacts and co-operation in the scientific and cultural fields'.
} 
and material of social and cultural benefit to the child; ${ }^{79}$ protecting and assisting refugee children $;{ }^{80}$ preventive health care and treatment of children with disabilities, ${ }^{81}$ health; ${ }^{82}$ and education. ${ }^{83}$ Article 45 explains the mandate of the UN Committee on the Rights of the Child to encourage international cooperation by liaising between various relevant actors.

The Convention on the Rights of Persons with Disabilities has a similar general implementation provision as the Convention on the Rights of the Child, ${ }^{84}$ and brings the matter even to a higher level by featuring a lengthy separate article on international cooperation in general terms. This article precedes the one on national implementation and monitoring. ${ }^{85}$ Likewise, the mandate of the Committee on the Rights of Persons with Disabilities also explicitly extends to encouraging international cooperation. ${ }^{86}$

Due to the nature of the topic covered, it is not unexpected that the International Convention for the Protection of All Persons Against Enforced Disappearance, in its Article 15, contains 'only' a rather specific and modest international cooperation obligation:

States Parties shall cooperate with each other and shall afford one another the greatest measure of mutual assistance with a view to assisting victims of enforced disappearance, and in searching for, locating and releasing disap-

\footnotetext{
79 Convention on the Rights of the Child, Art. 17(a) and (b), adopted 20 November 1989, entry into force September 1990, 196 States Parties on 1 July 2016 according to https://treaties.un.org.

80 Ibid., Art. 22(2).

81 Ibid., Art. 23(4) clarifies that 'States shall promote, in the spirit of international cooperation, the exchange of appropriate information [...] including dissemination of and access to information concerning methods of rehabilitation, education and vocational services [...]. [...] [P] articular account shall be taken of the needs of developing countries'.

82 Ibid., Art. 24(4), which demands particular account to be taken of the needs of developing countries.

83 Ibid., Art. 28(4).

84 Convention on the Rights of Persons with Disabilities, adopted 13 December 2006, entry into force on 3 May 2008; 195 States Parties on 1 July 2016 according to https://treaties.un.org. See general implementation Art. 4 which formulates international cooperation obligations where needed in relation to economic, social and cultural rights.

85 Ibid. This (very interesting) Art. 32 reads as follows: '1. States Parties recognize the importance of international cooperation and its promotion, in support of national efforts for the realization of the purpose and objectives of the present Convention, and will undertake appropriate and effective measures in this regard, between and among States and, as appropriate, in partnership with relevant international and regional organizations and civil society, in particular organizations of persons with disabilities. Such measures could include, inter alia: (a) Ensuring that international cooperation, including international development programmes, is inclusive of and accessible to persons with disabilities; (b) Facilitating and supporting capacity-building, including through the exchange and sharing of information, experiences, training programmes and best practices; (c) Facilitating cooperation in research and access to scientific and technical knowledge; (d) Providing, as appropriate, technical and economic assistance, including by facilitating access to and sharing of accessible and assistive technologies, and through the transfer of technologies. 2. The provisions of this article are without prejudice to the obligations of each State Party to fulfil its obligations under the present Convention'.
}

86 Ibid., Arts. 37 and 38. 
peared persons and, in the event of death, in exhuming and identifying them and returning their remains. ${ }^{87}$

All in all, the various UN human rights treaties presented above-covering a wide range of important issues relating to economic, social and cultural rights, children's rights, persons with disabilities and the phenomenon of enforced disappearance-provide a solid and concrete legal basis and a reason for further operationalizing international cooperation for development. The UN treaty bodies involved have already acted upon this to some extent by referring to international cooperation and/or assistance in quite a few of their General Comments. ${ }^{88}$ In doing so, the Committee on Economic, Social and Cultural Rights has not only referred several times to the obligations of States to contribute to international cooperation, but also indicated that States Parties which lack national resources for achieving the progressive realization of economic, social and cultural rights 'have an obligation to seek international cooperation and assistance'. ${ }^{89}$ In this way, at least in legal terms, the circle of the duty to cooperate has been closed.

A feasible way forward in terms of RTD implementation action would be for the treaty bodies involved to pay more attention to relevant aspects of the duty to cooperate for human rights and development in the State reporting procedures that they conduct. This would entail that they enquire more frequently and more explicitly than is currently the case whether governments sufficiently provide or request international cooperation and assistance, according to what applies in the particular case.

A further impetus could be found in the SDGs. After all, when endorsing the SDGs, the UN Member States referred to the goal of achieving the SDGs as a 'collective journey'. 90 They also expressed their determination 'to mobilize the means required to implement this Agenda through a revitalized Global Partnership for Sustainable Development, based on a spirit of strengthened global solidarity'. ${ }^{91}$

\footnotetext{
87 International Convention for the Protection of All Persons Against Enforced Disappearance, adopted 20 December 2009, entry into force 23 December 2010. According to this Convention, enforced disappearance is brought about by 'agents of the State or by persons or groups of persons acting with the authorization, support or acquiescence of the State'. Ibid., Art. 2. It follows that this is a rather sensitive matter, which perhaps makes intergovernmental cooperation rather complex.

88 In a General Comment (GC) a treaty body publishes its interpretation of the content of the human rights treaty that it has under its wing. Since 1989, the Committee on Economic, Social and Cultural Rights has adopted 23 GCs. Only four of these lack references to international cooperation/assistance (GC no. 7 (1997) on forced evictions, GC no. 9 (1998) on the domestic application of the Covenant, GC no. 10 (1998) on the role of national human rights institutions and GC no. 16 (2005) on the equal right of men and women to the enjoyment of economic, social and cultural rights). Since 2001 the Committee on the Rights of the Child has issued 17 GCs. All except two of these refer (succinctly or elaborately) to international cooperation and/or assistance. The exceptions are GCs nos. 10 (2007) on juvenile justice, and 12 (2009) on the right to be heard. Until now, the Committee on the Rights of Persons with Disabilities has adopted two GCs. The second one, adopted in 2014 and addressing accessibility, contains multiple references to international cooperation.

89 This statement was made in relation to the right to just and favourable conditions of work. Committee on Economic, Social and Cultural Rights, 'General Comment No. 23 (2016) on the Right to Just and Favourable Conditions of Work (Art. 7 of the International Covenant on Economic, Social and Cultural Rights)', UN Doc. E/C.12/GC/23, 27 April 2016, para. 52.

90 Agenda 2030, Preamble, above n. 2, at p. 1.

91 Ibid., at p. 2.
} 
Another interesting dimension could be that of stepping up South-South international cooperation, although for the time being this could only complement-and not replace-North-South cooperation. A current example is that of the India Brazil South Africa (IBSA) Dialogue Forum. This Forum was established in June 2003 because of 'the necessity of a process of dialogue among developing nations and countries of the South to counter their marginalisation'. ${ }^{92}$ The three States involved collaborate in IBSA because they are determined to: contribute to the construction of a new international architecture; bring their voices together on global issues; and deepen their ties in various areas. They also conduct 'concrete projects of cooperation and partnership with less developed countries'. ${ }^{93}$ While thus this has made a potentially promising start, this seems not yet to have generated an allencompassing policy practice. For example, there are reports that the foreign economic policies of IBSA States 'deliberately but also unintentionally create suboptimal conditions for the development of some of their Southern neighbours'. 94

\subsection{Strengthening Accountability}

Another vital element in pushing for more implementation action concerning the RTD is that of assigning more concrete responsibilities to both rights holders and duty bearers. The more vigilant role for the UN human rights treaty bodies that we proposed in the previous section could also contribute to processes of assigning such specific responsibilities. Obviously, monitoring the extent to which States actually perform their RTD obligations-for example in relation to making available or demanding international assistance-would then become more useful and so perhaps more achievable. In this way the State reporting procedures concerning the International Covenant on Economic, Social and Cultural Rights, the Convention on the Rights of the Child, the Convention on Persons With Disabilities, and to a lesser extent the International Convention on the Protection of All Persons from Enforced Disappearance, could turn into monitoring possibilities for the specific RTD elements that are relevant to the human rights treaty involved. Once such practice has taken off, over time this could perhaps even inspire greater attention for RTD issues in the work of the Human Rights Council, ${ }^{95}$ more in particular in the Universal Periodic Review process by which the Council reviews the overall human rights records of all UN Member States.

\footnotetext{
92 As stated on the IBSA members site, http://www.ibsa-trilateral.org/.

93 Ibid., http://www.ibsa-trilateral.org/about-ibsa/background. For more information see South Centre, 'South-South Cooperation Dialogue Held in the UN, Geneva', South News, no. 111, 4 July 2016.

94 Nel and Taylor (2013), pp. 1091-1110, at p. 1091.

95 At the moment the Human Rights Council annually receives a report from the Intergovernmental Working Group on the Right to Development as regards implementation aspects of the right to development, see http://www.ohchr.org/EN/Issues/Development/Pages/WGRightToDevelopment.aspx and above n. 25. Sometimes concrete follow-up action is requested. For an overview of the Human Rights Council involvement so far, see Human Rights Council, 'Report of the Working Group on the Right to Development on its Sixteenth Session (Geneva, 27 April, 1-4 September 2015)', UN Doc. A/HRC/30/71, 28 October 2015, pp. 3-4.
} 
On the one hand, the suggestions above might seem idealistic and/or naïve. After all, most of the global efforts to further specify the implications of the RTD have stranded. One of the more recent examples is the work of the High Level Task Force on the Right to Development. The set of operational criteria and the list of indicators for the implementation of the RTD that the Task Force developed reportedly appear 'to have brought the political divisions to a head'. ${ }^{96}$ On the other hand, there might be a new straw to seize, in that the process around the formulation of the SDGs has clearly generated a renewed emphasis on concrete targets, on data as a basis for evidence-based monitoring and on the development of concrete sustainable development indicators. ${ }^{97}$ It remains to be seen, however, how strong or weak this straw will turn out to be. While the 'Follow-Up and Review' section of Agenda 2030 as such is relatively elaborate and comprehensive, it is utterly disappointing that the review process is stated to be an entirely 'voluntary and country-led' process and that 'the global review will be based primarily on national official data sources'. ${ }^{98}$ According to Shahra Razavi, Chief of Research and Data of UN Women since mid-2013, 'there was complete consensus' among the UN Member States about keeping the review process voluntary, 'regardless of their regional, political, or ideological differences on other issues'. ${ }^{99}$ We fully agree with her that, 'given the explicit human rights anchoring of the new Agenda, it is doubly disappointing that Member States did not break any new ground in subjecting themselves' to more robust monitoring systems. ${ }^{100}$

\subsection{Using Regional and Inter-Regional Understandings of the RTD}

As outlined in Sect. 2 above, some binding regional and inter-regional instruments have also incorporated RTD content or inspired RTD implementation efforts. These might provide leads for revitalizing the RTD as well. The most direct and prominent example of such an instrument is Article 22 of the African Charter on Human and Peoples' Rights. The former Prince Claus Chair Holder in Development and Equity Olajumoke Oduwole, who during her tenure of this Chair focused her work on the RTD, has noted that this Article is understudied. She also observed that:

the relevance of this regional right to analysis of the universal RTD lies in its contextual guidance regarding the original intent of the African developing country players who initiated this right at the regional level, as well as the continent's contribution in the area of jurisprudence on the RTD so far. ${ }^{101}$

\footnotetext{
96 Fukuda-Parr (2012), p. 847. For the contents of the criteria and indicators, see Human Rights Council, 'Report of the High-Level Task Force on the Implementation of the Right to Development on its Sixth Session', UN Doc. A/HRC/15/WG.2/TF/2/Add.2, 8 March 2010.

97 See Agenda 2030, above n. 2, Declaration paras. 48 and 57 and SDG Targets 17.18 and 17.19; and Statistical Commission, 'Report of the Inter-Agency and Expert Group on Sustainable Development Goal Indicators: Note by the Secretary-General', UN Doc. E/CN.3/2016/2/Rev.1, 19 February 2016.

98 Agenda 2030, Declaration para. 74(a).

99 Razavi (2016), p. 38.

100 Ibid., partly quoting Reddy and Kvangraven (2015), p. 13.

101 Oduwole (2014).
} 
It is in this regard indeed that the African perspective on the RTD could be an inspiration for the revitalization or operationalization of the RTD at the global level.

Important developments have been recorded at the African regional human rights system regarding both the conceptual and operational understanding of the RTD. The African Charter on Human and Peoples' Rights, referred to in short as the Banjul Charter, remains the only tested international instrument on the RTD with an emerging quasi-jurisprudence on the subject. At least seven of the over 229 decisions that had been rendered by the African Commission up until June 2016 have relevance for the RTD. These cases either explicitly involved the RTD, or are strongly relevant to it, for example because they address pertinent economic, social and cultural aspects of development. ${ }^{102}$ As already stated in Sect. 2 above, Article 22 of the African Charter stipulates that '[a]ll peoples shall have the right to their economic, social and cultural development with due regard to their freedom and identity and in the equal enjoyment of the common heritage of mankind' and that 'States shall have the duty, individually or collectively, to ensure the exercise of the right to development'. ${ }^{103}$ Although Obiora Okafor has noted that the content of Article 22 'remains obscure as to the nature of the concept of development [...] [especially as] no detailed developmental programme can be deciphered from [its] reading', implementation practice under this clause could provide a useful perspective on potential options for revitalizing the RTD in international law. ${ }^{104}$ Okafor thought so too and in a 2013 publication already advocated that a 'globally contextualized analysis of article 22' of the African Charter might even hold important lessons for 'any anticipated global treaty on the right to development'. ${ }^{105}$ According to Okafor, the developments in the African regional human rights system have established that:

any conception of development under article 22 must, at a minimum: (a) frame the process and goals of development as constituted in part by the enjoyment of peace; (b) envision the process and ends of development in part through a human rights optic; (c) view the gender, ethnic and other such inequities that exist in the distribution of developmental benefits as a lack of development; (d) imagine the people's participation in their own development as an irreducible minimum; and (e) imagine the right to development as inclusive of the rights to the means, processes and outcomes of development. ${ }^{106}$

\footnotetext{
102 Ibid., at p. 17. For further analysis on the Decisions of the African Commission, see African Human Rights Case Law Analyser, accessible via http://caselaw.ihrda.org/body/acmhpr/. The term quasijurisprudence refers to the fact that the complaints procedure involved generates recommendations which 'are not in themselves legally binding on the States concerned'. These recommendations are included, however, in the Commissioner's Annual Activity Reports that are sent to the Assembly of Heads of State and Government of the $\mathrm{AU}$, which, under certain circumstances, e.g. could request a further study of the case(s) involved. According to Oduwole (2014), n. 141 at p. 29, the African Commission's findings are 'persuasive and generally well-respected'. See Arts. 55-58 of the Banjul Charter and, for more background, http://www.achpr.org/communications/procedure/.

103 Above n. 18.

104 See generally Okafor (2013), pp. 373-384.

105 Ibid., at p. 378.

${ }^{106}$ Ibid.
} 
For our purposes, it is indeed most important to consider how the African Commission has interpreted and given meaning to Article 22. So far, the African Commission's most well-known decision regarding a violation of Article 22 of the African Charter is that in the Endorois case. This case involved the forced removal in the 1970s of the Endorois (a pastoralist group) from their ancestral land on which they had lived for centuries, to set up a national game reserve and tourist facilities. ${ }^{107}$ The complainants in this case raised several violations of their rights under the African Charter, including their RTD under Article 22. In the 2009 decision in this case, the African Commission found that the Kenyan government had indeed violated Article 22. It clarified the content of the RTD by noting:

that the right to development is a two-pronged test, that it is both constitutive and instrumental, or useful as both a means and an end. A violation of either the procedural or substantive element constitutes a violation of the right to development. Fulfilling only one of the two prongs will not satisfy the right to development. The African Commission notes the Complainants' arguments that recognizing the right to development requires fulfilling five main criteria: it must be equitable, non-discriminatory, participatory, accountable, and transparent, with equity and choice as important, overarching themes in the right to development. In that regard it takes note of the report of the UN Independent Expert who said that development is not simply the state providing, for example, housing for particular individuals or peoples; development is instead about providing people with the ability to choose where to live. He states '.. the state or any other authority cannot decide arbitrarily where an individual should live just because the supplies of such housing are made available'. Freedom of choice must be present as a part of the right to development. ${ }^{108}$

In the earlier case of Democratic Republic of the Congo v. Burundi, Rwanda and Uganda the African Commission had already shed light on the meaning of the RTD as well as the entitlements and duties that follow. ${ }^{109}$ In adjudicating this case, that concerned regional military interference in the Democratic Republic of the Congo, the African Commission noted that:

[t]he deprivation of the right of the people of the Democratic Republic of Congo, in this case, to freely dispose of their wealth and natural resources, has also occasioned another violation-their right to their economic, social and cultural development and of the general duty of states to individually or collectively ensure the exercise of the right to development, guaranteed under article 22 of the African Charter. ${ }^{110}$

\footnotetext{
107 African Commission on Human and Peoples' Rights, Case Centre for Minority Rights Development (Kenya) and Minority Rights Group International on behalf of the Endorois Welfare Council v. The Republic of Kenya, Communication No. 276/2003, 25 November 2009, http://www.achpr.org/ communications/decision/276.03/.

108 Ibid., paras. 277-278, emphasis as in the original.

109 Democratic Republic of the Congo v. Burundi, Rwanda and Uganda, Communication 227/99, 29 May 2003, http://www.achpr.org/communications/decision/227.99/.

110 Ibid., at para. 95.
} 
This specific interpretation of the RTD in a growing body of quasi-jurisprudence by the African Commission contrasts with, and could usefully complement, the more abstract current debates at the global level.

Article 22 of the Banjul Charter as interpreted by the African Commission is instrumental in at least two ways. Firstly, at the conceptual level, it offers a more detailed understanding of the RTD. Secondly, at the enforcement level, the African system might hold clues for those who advocate similar accountability or enforcement structures at the global level. The African model, its achievements, effectiveness and challenges could provide some critical thoughts, for example for those supporting a global treaty on the RTD, and thereby it would be useful to analyse and publicise these more than has been the case so far.

The other example of a treaty operating at the inter-regional level and relevant for RTD debates that was presented in Sect. 2 above is the ACP-EU Cotonou Agreement. The current version of this treaty, that provides the framework for international development cooperation between in total 107 States in Europe, Africa, the Caribbean and the Pacific, will expire in 2020. While this treaty does not refer to the RTD as such, its implementation practice shows several highly relevant features. ${ }^{111}$ In the run-up to the start of the renegotiations on terms of collaboration between the ACP and the EU, there are signs that several of the achievements established in the past may be at risk. This extends, for example, to the principle of joint management of the cooperation activities and the relationship as such. Some EU Member States as well as some forces in the European Commission would not mind doing away with this aspect and returning to a more unilaterally directed basis for ACP-EU relations. ${ }^{112}$ This would seriously affect the participation of the ACP States in the process and so cut back on an important aspect of the RTD. There might be space, however, for curbing such tendencies, should they materialize as official positions later on in the formal negotiation process. This space might be found in the EU Action Plan on Human Rights and Democracy 2015-2019, in which the Union has committed itself 'to move towards a rights based approach to development cooperation, encompassing all human rights by pursuing its full concrete integration into all EU development instruments and activities' and 'to contribute to discussions on the right to development'. ${ }^{113}$ Renegotiating the terms of ACP-EU collaboration will become an important litmus test for the EU's commitment to its self-imposed policy priorities.

\section{Conclusion}

This article has explored the scope for revitalizing the RTD through existing international law instruments, rather than by creating additional normative frameworks. In analysing the state of the RTD 30 years after the adoption of

\footnotetext{
${ }^{111}$ Section 2 above, nn. 20 and 21.

${ }^{112}$ For an overview of the achievements and challenges of the ACP-EU partnership in light of the expiration of the Cotonou Agreement, see Advisory Council of International Affairs (2015).

113 EU Action Plan on Human Rights and Democracy 2015-2019, 10897/15, Brussels 20 July 2015, adopted paras. 27(a) and (c).
} 
the UNDRTD, we found a mixed picture. On the one hand, the protracted debate and controversy over the RTD have more or less ended up in a stalemate at the global level, with the exception of selected UN human rights instruments and the SDGs process that we have discussed. While Agenda 2030 is directly inspired by rights-based approaches to development and the RTD, the possible hope that this may generate for revitalizing the RTD is tempered by the fact that the SDGs themselves and the attached Targets do not represent a firm rights orientation. Accordingly, we have pointed out modest potential (and partly alternative) spaces for revitalizing the RTD and its implementation efforts on the basis of, respectively:

- a better understanding of the law on international cooperation and related obligations, especially as taken up by UN human rights treaty bodies;

- creating accountability processes, which include monitoring the extent to which States actually perform their RTD obligations; and

- learning from regional experiences on concretizing the RTD such as the ones thus far gained most notably in the African regional system.

Though not exclusive of other elements, in our view these three aspects certainly are germane to future understandings of the RTD and to the potential realization of this right in the coming period. In particular, they reinforce the argument that, notwithstanding current contestations, the core elements of the RTD already exist firmly in international law. As Fantu Cheru has stated: 'the UN Charter and the accompanying two human rights covenants establish the foundations for an ethical system of global governance'. ${ }^{114}$ While we acknowledge that RTD practice is scattered at best, and insufficient overall—and that this is due to the differences in persistent economic, political and ideological interests of 'developed' and 'developing' States-we also note that at the regional level the African human rights system is in the process of producing a fuller understanding of the RTD that supports its further definition (both in terms of substance and implementation obligations) and its enforceability. States across the globe would do well to take up the challenges of operationalizing and practising the RTD now, through both national and international means and measures. Besides serving to fulfil the RTD, this would also be a tremendous step forward in tackling current global problems relating to structural poverty and inequalities, contagious diseases, climate change and mass migration.

Open Access This article is distributed under the terms of the Creative Commons Attribution 4.0 International License (http://creativecommons.org/licenses/by/4.0/), which permits unrestricted use, distribution, and reproduction in any medium, provided you give appropriate credit to the original author(s) and the source, provide a link to the Creative Commons license, and indicate if changes were made.

114 Cheru (2016), pp. 1277-1278. 


\section{References}

Advisory Council of International Affairs (2015) ACP-EU cooperation after 2020: towards a new partnership? Advisory Report No 93. The Hague, 31 August 2015. http://aiv-advies.nl/84h. Accessed 10 Oct 2016

Alston P (1988) Making space for new human rights: the case of the right to development. Harvard Hum Rights Yearb 1:3-40

Arts K (1996) Implementing the right to development? An assessment of European Community development cooperation. In: Baehr P et al (eds) Human rights in developing countries yearbook 1996. Kluwer Law International/Nordic Human Rights Publications, The Hague/Oslo, pp 37-74

Arts K (2008) The European Community's contribution to the fight against poverty in developing countries: normative and real? Ger Yearb Int Law 51:217-250

Bartels L (2005) Human rights conditionality in the EU's international agreements. Oxford University Press, Oxford

Bulajić M (1986) Principles of international development law. Martinus Nijhoff Publishers, Dordrecht

Cheru F (2016) Developing countries and the right to development: a retrospective and prospective African view. Third World Q 37:1268-1283

Chowdhury SR, Denters EMG, De Waart P (1992) The right to development in international law. Law Research Institute/Martinus Nijhoff Publishers, Calcutta/Dordrecht

Enns $C$ et al (2014) Indigenous voices and the making of the post-2015 development agenda: the recurring tyranny of participation. Third World Q 35:358-375

Frowein J (2016, article last updated December 2008) Obligations erga omnes. In: Wolfrum R (ed), Max Planck encyclopedia of public international law. Oxford University Press, Oxford (online)

Fukuda-Parr S (2012) The right to development: reframing a new discourse for the twenty-first century. Soc Res Int Q 79:839-864

Gabizon S (2016) Women's movements' engagement in the SDGs: lessons learned from the Women's Major Group. Gend Dev 24:99-110

Holland M (2002) The European Union and the third world. Palgrave, Basingstoke

Ibhawoh B (2011) The right to development: the politics and polemics of power and resistance. Hum Rights Q 33:76-104

Karimova T (2016) Human rights and development in international law. Routledge, London and New York

M'baye K (1972) Le droit au développement comme un droit de l'homme. Revue des Droits de l'Homme 5:503-534

Meillan L (2003) The right to development and the United Nations. Droit en Quart Monde 34:13-31

Murray R (2005) Human rights in Africa: from the OAU to the African Union. Cambridge University Press, Cambridge

Nel P, Taylor I (2013) Bugger thy neighbour? IBSA and South-South solidarity. Third World Q 34:1091-1110

Oduwole OO (2014) International law and the right to development: a pragmatic approach for Africa. International Institute of Social Studies, The Hague

Okafor OC (2013) A regional perspective: Article 22 of the African Charter on Human and Peoples' Rights. Office of the High Commissioner for Human Rights, Realizing the right to development: essays in commemoration of 25 years of the United Nations Declaration on the Right to Development. United Nations, New York and Geneva, pp 373-384

Ouguergouz F (2003) The African Charter on Human and Peoples' Rights: a comprehensive agenda for human dignity and sustainable democracy in Africa. Martinus Nijhoff Publishers, The Hague

Pillay N (2013) Foreword. In: Office of the High Commissioner for Human Rights, Realizing the right to development: essays in commemoration of 25 years of the United Nations Declaration on the Right to Development. United Nations, New York and Geneva, pp iii-v

Piron L (2002) The right to development: a review of the current state of the debate for the Department for International Development. Overseas Development Institute, London. https://www.odi.org/sites/ odi.org.uk/files/odi-assets/publications-opinion-files/2317.pdf. Accessed 10 Oct 2016

Rajagopal B (2013) Right to development and global governance: old and new challenges twenty-five years on. Hum Rights Q 35:893-909

Razavi S (2016) The 2030 Agenda: challenges of implementation to attain gender equality and women's rights. Gend Dev 24:24-41 
Reddy SG, Kvangraven IH (2015) Global Development Goals: if at all: why, when and how? http:// papers.ssrn.com/sol3/papers.cfm?abstract_id=2666321. Accessed 10 Oct 2016

Salomon M (2007) Global responsibility for human rights: world poverty and the development of international law. Oxford University Press, Oxford

Scott J, Harnam S (2013) Beyond TRIPS: why the WTO's Doha Round is unhealthy. Third World Q $34: 1361-1376$

Sengupta AK (2013) Conceptualizing the right to development for the twenty-first century. Office of the High Commissioner for Human Rights, Realizing the right to development: essays in commemoration of 25 years of the United Nations Declaration on the Right to Development. United Nations, New York and Geneva, pp 67-87

Stokke O (2009) The UN and development: from aid to cooperation. Indiana University Press, Bloomington

Turshen M (2014) A global partnership for development and other unfulfilled promises of the Millennium Project. Third World Q 35:345-357

Umozurike O (1997) The African Charter on Human and Peoples' Rights. Nijhoff Publishers, The Hague

UNICEF (2016) The State of the World's Children 2016: a fair chance for every child. Division of Communication, UNICEF, New York

Vandenbogaerde A (2013) The right to development in international human rights law: a call for its dissolution. Neth Q Hum Rights 31:187-209

Viljoen F (2012) International human rights law in Africa. Oxford University Press, Oxford

Villaroman NG (2010) The right to development: exploring the legal basis of a supernorm. Fla J Int Law 22:299-332

Villaroman N (2011) Rescuing a troubled concept: an alternative view of the right to development. Neth Q Hum Rights 29:13-53

Karin Arts is Professor of International Law and Development at the International Institute of Social Studies (ISS) of Erasmus University Rotterdam.

Atabongawung Tamo is currently an Affiliated Researcher with the Governance, Globalization and Social Justice Research Programme at the International Institute of Social Studies (ISS) of Erasmus University Rotterdam. 